\title{
Initial Resuscitation of a Multisystem Trauma Patient Following a Fall From Height: A Complete Simulation Scenario for Medical Students
}

\author{
Leah O. Grcevich ${ }^{1}$, Maxwell J. Jabaay ${ }^{1}$, Benjamin T. Leicht ${ }^{1}$, James Lyons ${ }^{2}$ \\ 1. Department of Research, Alabama College of Osteopathic Medicine, Dothan, USA 2. Department of Clinical Sciences, \\ Alabama College of Osteopathic Medicine, Dothan, USA
}

Corresponding author: Leah O. Grcevich, grcevichl@acom.edu

\begin{abstract}
Management of a complex trauma patient is a critical skill for medical students, particularly during a general surgery or emergency medicine clerkship. However, gaining proficiency with this skillset may be challenging without prior medical or simulation experience. The aim of this technical report is to present a comprehensive high-fidelity medical simulation of a polytraumatized patient with numerous injuries sustained from a 20 -foot fall. As the scenario unfolds, students identify multisystem injuries including acute hemorrhage, femur fracture, tension pneumothorax, and traumatic brain injury. The case was designed as an assessment tool to evaluate the knowledge of preclinical medical students obtained through a one-day workshop on the primary survey. This technical report provides simulation designers with a premade script, flowchart, labs, images, and supplies needed to successfully recreate the case.
\end{abstract}

Review began 01/05/2021 Review ended 01/30/2021 Published 01/30/2021

\section{๑) Copyright 2021}

Grcevich et al. This is an open access article distributed under the terms of the Creative Commons Attribution License CC-BY 4.0., which permits unrestricted use, distribution, and reproduction in any medium, provided the original author and source are credited.
Categories: Emergency Medicine, Medical Simulation, Trauma

Keywords: simulation in medical education, simulation design, emergency medicine resuscitation, trauma management, traumatic injury, pneumothorax (ptx), femur and fracture, life-threatening bleeding, medical education

\section{Introduction}

Traumatic injury represents a significant public health concern in the United States, with 20 million traumarelated discharges annually, representing 4.4\% of all-cause hospital discharges between 2000 and 2011 [1]. Traumatic injury is the number one cause of shortened lifespan in those under the age of 65 years [2]. The most common mechanism of trauma is a fall (comprising $47 \%$ of all injuries) and is common among all ages $[1,3]$. In recent years, other mechanisms of injury such as motor vehicle collisions have seen a decrease in case fatality, while mortality from falls has increased by $46 \%$ [4]. Trauma patients have worse long-term survival than age-matched controls, and long-term survival is correlated with existing comorbidities and location of discharge (home versus skilled nursing facility) [5]. Multisystem trauma patients represent some of the most complex cases received by trauma physicians. Within the context of this paper, multisystem trauma is referring to a mechanism of injury involving two or more body systems or regions [6].

The following simulation scenario involves the management of a multisystem trauma patient whose injuries were incurred following a fall from 20 feet. This scenario was originally developed as an assessment tool for a comprehensive one-day curriculum, in which medical students were instructed on how to perform the primary survey [7]. Goals for the event were based on the five components of the primary survey including evaluation and management of airway, breathing, circulation, disability, and exposure (ABCDE). This case functioned as a final assessment tool; it was designed to test students' ability to think critically and apply key components of the primary survey to treat a polytraumatized patient.

\section{Technical Report \\ Learning objectives}

Each learning objective corresponds with a component of the primary survey (ABCDE):

1. A - Identify a patent airway.

2. B - Identify a tension pneumothorax based on auscultatory and chest x-ray findings.

3. B - Verbalize or perform a needle decompression to treat a tension pneumothorax.

4. C - Identify hypovolemic shock and its proximal cause.

5. C - Treat the underlying cause of hypovolemia by applying a tourniquet or pressure dressing, and support systemic circulation by administering fluids or blood products. 
6. D - Identify a traumatic brain injury.

7. E - Remove the patient's clothing to identify injuries.

8. Perform a concise handoff.

\section{Context}

This simulation was run as part of a workshop on the primary survey [7]. The intended audience was preclinical medical students but could be adapted to include higher level providers with some additions to the case. This case was run in a medical school simulation center as if the patient was just transferred to an emergency department (ED) trauma bay from emergency medical services (EMS). This case could be adapted for in-situ simulation in a variety of inpatient and outpatient environments.

The case is designed so that each component of the primary survey needed to be addressed based on the patient's evolving condition. The scenario is presented as a progressively unfolding encounter so that after a successful intervention is made the team must reassess ABCD as the patient continues to decompensate. Students approach this simulation in teams of five. Within each group, every student has a predefined role: team leader, history taker, physical examiner, proceduralist, and scribe. In addition, each simulation room includes one healthcare actor (HA) taking on the role of an ED nurse. The role of the HA is to provide guidance if the team veers too far off track and allow learners to progress through the scenario before the patient deteriorates [8].

\section{Inputs}

The following is a list of props, personnel, and equipment required to run the simulation. Alternatives and substitutions are recommended where applicable.

1. A standardized patient (SP) who had memorized a patient script (Appendix A) for the case and who was trained in the overall case flow (Appendix B) in order to cue the participants if needed

2. An ED nurse if available or a HA trained on the case flow embedded in the scenario to control the situation, should a team become preoccupied with non-vital information

3. Simulation facilitator to provide vital signs, imaging, etc. to the monitor in the room or provide paper copies (labs included in Appendix C and imaging included as figures throughout)

4. Purple and black makeup applied behind the ears to indicate battle signs (Figure $1 \mathrm{~A}$ )

5. Prop open femur fracture (Figure $1 B$ ) with an attached prop blood bag filled with fake blood (see Appendix D)

6. Prop clothing that can be cut with trauma shears or pre-cut (Figure $1 \mathrm{C}$ )

7. Cervical collar positioned on the patient (Figure 1C)

8. Training tourniquet or gauze

9. Red and purple makeup applied to right chest overlying site of tension pneumothorax 


\section{Cureus}

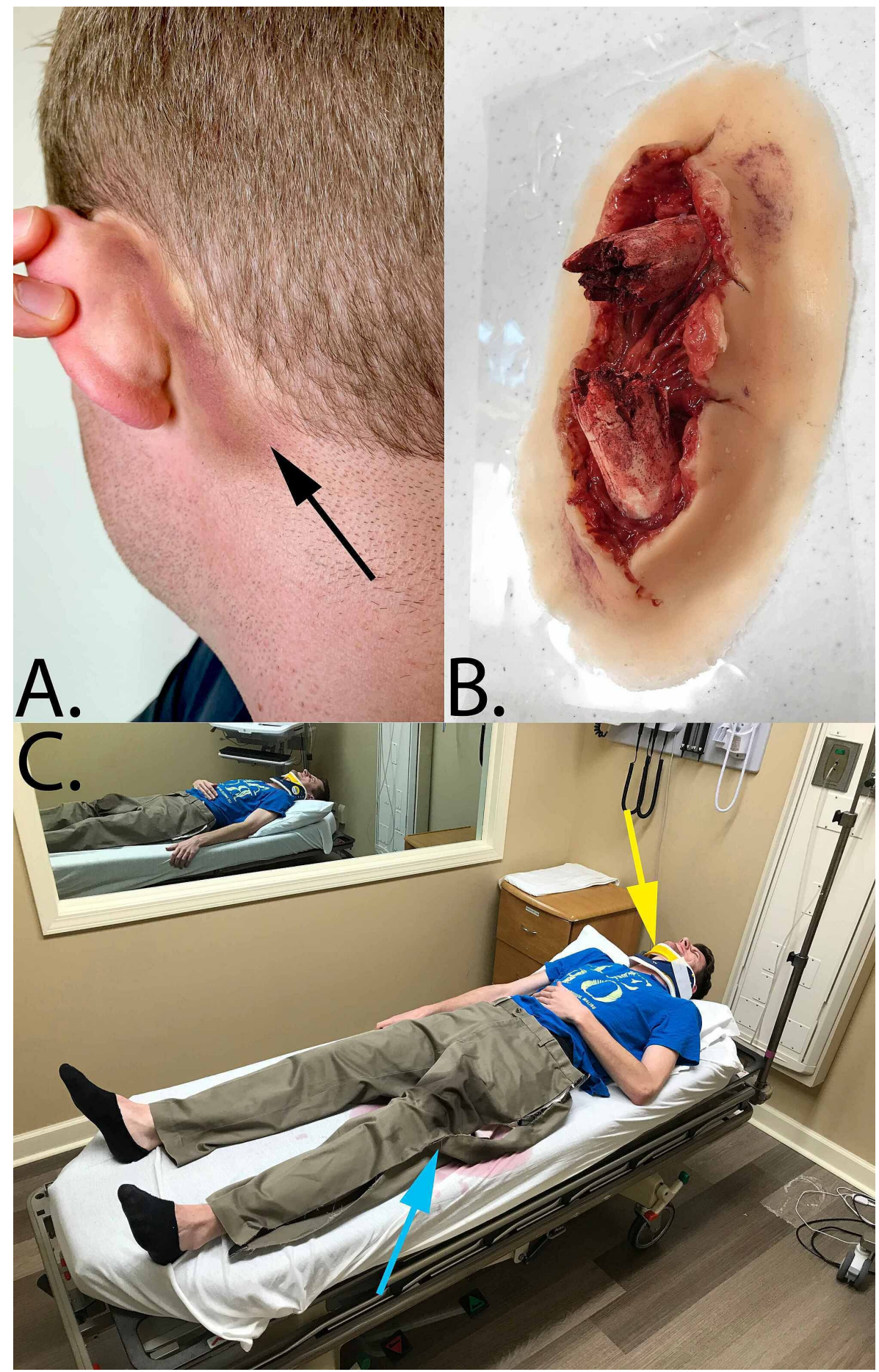

\section{FIGURE 1: Simulation props}

(A) The black arrow highlights dark makeup which was applied behind the ears to mimic retroauricular ecchymosis. (B) Silicone prosthetic was applied to the thigh of the SP to simulate a compound femur fracture. (C) At the beginning of the scenario, students encounter a human SP (or high-fidelity simulator) fully dressed in a hospital bed with cervical collar in place. The yellow arrow is pointing to the location of the cervical collar in the image. The light blue arrow highlights the pre-cut clothing to facilitate easy exposure of the patient.

SP, Standardized patient.

\section{Preparation timeline}

1. Two weeks prior to beginning this simulation, SPs are provided their script and brought back for a training session to explain the flow of the case and to practice reacting to the participants' questions. 


\section{Cureus}

2. Prior to the beginning of the case, each member of a team of five chooses to take on one of the following roles: team leader, physical examiner, history taker, scribe, and proceduralist.

3. The case begins with the team receiving a one-time oral report of the patient from the EMS. After obtaining the report, participants report to the simulation center or emergency room (ER) trauma bay.

4. Encounter is initiated by the team captain's introduction to the patient and continues with other team members completing a history and assessment.

5. The team assesses and treats the patient's life-threatening injuries. Upon reassessment, a new trauma sequela is presented, and the team must act accordingly. The patient will begin to deteriorate, or there will be a change in the patient's status only after the desired task is accomplished.

6. At the completion of the case, students report to be debriefed.

\section{Simulation scenario}

The case begins outside of an emergency room resuscitation bay, with the students receiving the following prerecorded EMS radio report (Video 1):

EMS report: "This is Houston county rescue five coming to your facility with a priority one trauma alert. We have a 25 -year-old male \{Glasgow Coma Scale score\} GCS 13, alert and oriented two out of three, negative to place, who fell from a height of 20 feet, and his left leg has taken most of the impact. The patient has a compound femur fracture. The patient has lost close to one liter of blood, and bleeding is not controlled. The patient's vitals are heart rate 130 , blood pressure 106/88, respiratory rate 22 , and $\mathrm{SpO} 2$ is $97 \%$ on room air. IV has been placed, and we have taken C-Collar precautions. We are three minutes away."

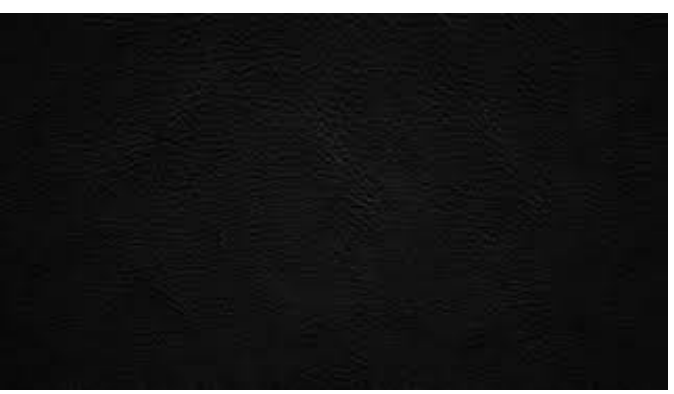

\section{VIDEO 1: EMS radio report}

EMS, Emergency medical services.

View video here: https://www.youtube.com/watch? v=f_cz_qrLvoM\&feature=youtu.be\&fbclid=IwARON14QzC2EVPQaUkXBtjF9Jb71McqhRrOR4YuJKVMYF8NWE8-I2ozLMZ4

Students are then allowed to enter the patient room. Vital signs, patient actions, expected student responses, and operator notes for the initial stage are included in Table 1. 


\section{Cureus}

\begin{tabular}{|c|c|c|c|}
\hline Vital signs & Patient status & Student actions & Operator notes \\
\hline $\begin{array}{l}\text { Pulse 138, } \\
\text { regular }\end{array}$ & $\begin{array}{l}\text { The patient initially has eyes closed } \\
\text { but will be able to open eyes and } \\
\text { answer questions when asked }\end{array}$ & Obtain a focused history & $\begin{array}{l}\text { If students do not know what to do, the patient } \\
\text { may state the following: "please help me - I think I } \\
\text { am going to bleed out." }\end{array}$ \\
\hline $\begin{array}{l}\text { Blood } \\
\text { pressure } \\
\text { (BP) } 104 / 72\end{array}$ & Bleeding wound & $\begin{array}{l}\text { Cut off the patient's } \\
\text { clothing }\end{array}$ & $\begin{array}{l}\text { If student's fail to address bleeding wound, the } \\
\text { patient states the following: "please, I'm going to } \\
\text { die if you don't stop the bleeding." }\end{array}$ \\
\hline $\begin{array}{l}\text { Respiratory } \\
\text { rate (RR) } \\
22\end{array}$ & $\begin{array}{l}\text { Patient is aware of events preceding } \\
\text { injury. }\end{array}$ & $\begin{array}{l}\text { Complete a rapid head-to- } \\
\text { toe physical }\end{array}$ & $\begin{array}{l}\text { If radiographic imaging of the head is ordered, } \\
\text { hold until the final state with altered mental status. }\end{array}$ \\
\hline $\begin{array}{l}\text { Pulse } \\
\text { oxygen } \\
\text { (SpO2) } \\
94 \%\end{array}$ & Pain is $8 / 10$. & $\begin{array}{l}\text { Address bleeding (either } \\
\text { pack or apply tourniquet) } \\
\text { and administer fluids }\end{array}$ & $\begin{array}{l}\text { If lower extremity } x \text {-ray is ordered, it may be } \\
\text { provided at this time. }\end{array}$ \\
\hline
\end{tabular}

\section{TABLE 1: Initial hypotensive state}

Student actions include a list of actions that must be completed by the students in order to move on to the next phase of the simulation. If students struggle to complete the requisite actions, these actions may be prompted by the standardized patient (by repeating the quotation listed within the operator notes) or by the healthcare actor.

As students enter the room, they find a distressed patient with uncontrolled bleeding associated with an open fracture, indicating life-threatening hemorrhage. This is accomplished by using a prop open femur fracture (Figure $1 B$ ) connected to a fake blood bag (Appendix D). The flow of blood from the wound is controlled by the SP pressing their back on the blood bag.

The focus of this stage is for students to identify massive hemorrhage and begin the primary survey with circulation rather than airway management. Patients in need of resuscitation usually follow an algorithm of airway, breathing, circulation $(\mathrm{ABC})$; however, in cases of massive hemorrhage, it is a standard practice to prioritize circulation before airway and breathing $(\mathrm{CAB})$ as oxygenation and ventilation attempts would be ineffective without adequate blood volume [9]. Actions required to move on to the next stage may be modified based on the level of the students. First- and second-year medical students are expected to identify and address the patient's bleeding through the application of a pressure dressing or tourniquet. These actions must be performed in conjunction with supporting the patient's blood pressure through the administration of fluids or blood products. Initial stabilization of the patient should take precedence prior to obtaining imaging. If an $\mathrm{x}$-ray was ordered following completion of the primary survey and appropriate interventions, imaging would confirm the diagnosis of open displaced femur fracture (Figure 2). 


\section{Cureus}

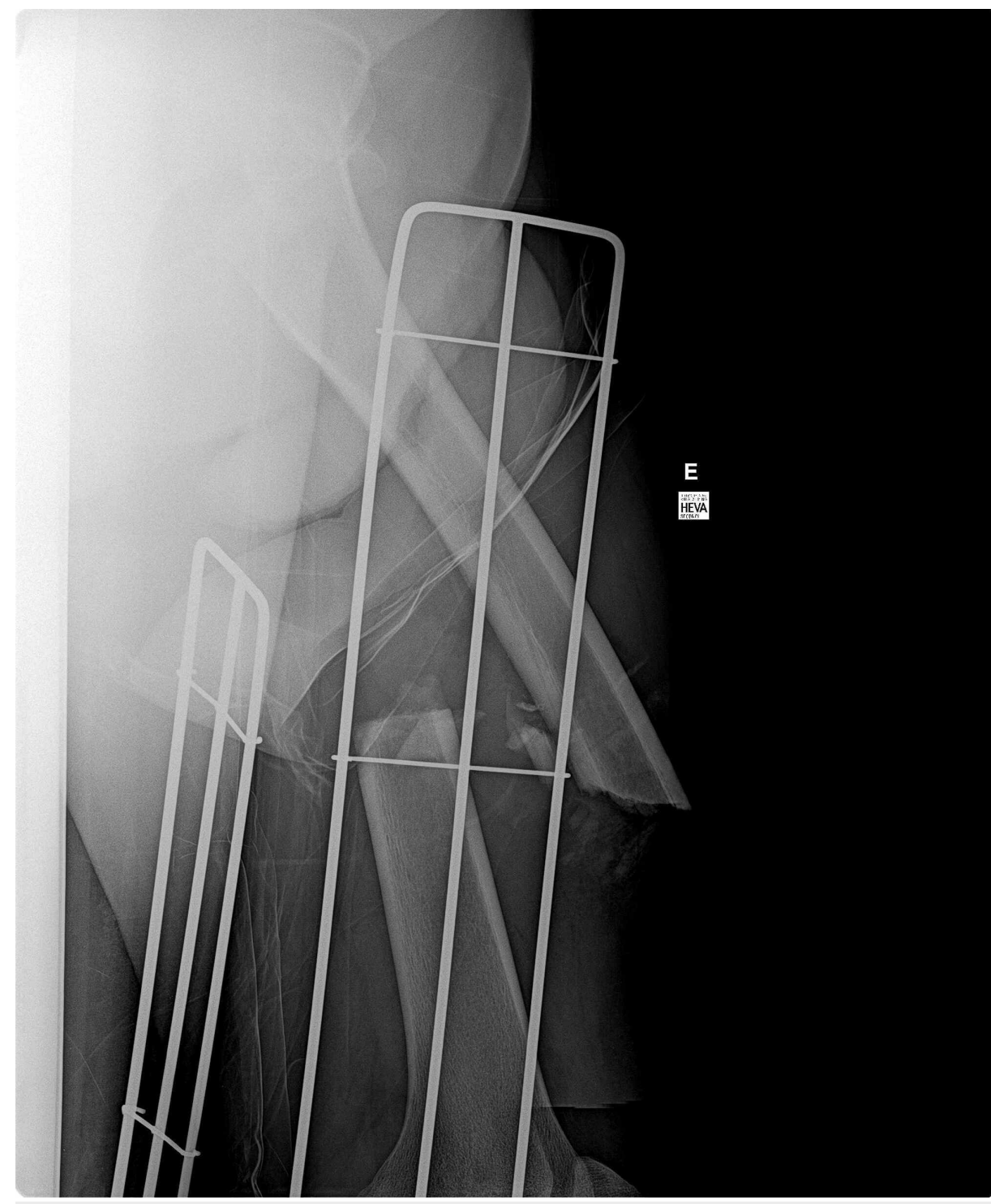

FIGURE 2: X-ray showing open displaced femur fracture

Case courtesy of Prof. Cláudio Souza, Radiopaedia.org, rID: 13772.

Following the primary assessment and hemorrhage control, the patient becomes confused and short of breath, as outlined in Table 2 . 


\section{Cureus}

\begin{tabular}{|c|c|c|c|}
\hline Vital signs & Patient status & $\begin{array}{l}\text { Student } \\
\text { actions }\end{array}$ & Operator notes \\
\hline HR 118 & $\begin{array}{l}\text { Patient is becoming more } \\
\text { confused. }\end{array}$ & $\begin{array}{l}\text { Auscultate } \\
\text { lungs, and } \\
\text { identify absent } \\
\text { breath sounds } \\
\text { on right }\end{array}$ & $\begin{array}{l}\text { If students do not apply oxygen or order a chest x-ray after } 1-2 \\
\text { minutes, the patient may state the following: "it feels like I have one } \\
\text { lung." }\end{array}$ \\
\hline BP 114/80 & $\begin{array}{l}\text { Patient complains of } \\
\text { shortness of breath and } \\
\text { chest pain }\end{array}$ & $\begin{array}{l}\text { Administer } \\
\text { supplemental } \\
\text { oxygen }\end{array}$ & $\begin{array}{l}\text { If students do not order chest x-ray after another minute, healthcare } \\
\text { actor asks "did we order all of the necessary trauma films?" }\end{array}$ \\
\hline RR 24 & & $\begin{array}{l}\text { Order chest } \mathrm{x}- \\
\text { ray }\end{array}$ & \\
\hline \multicolumn{4}{|l|}{ SpO2 90\% } \\
\hline \multicolumn{4}{|c|}{ Vital signs change after the chest $x$-ray is ordered } \\
\hline HR 142 & $\begin{array}{l}\text { Patient is more confused } \\
\text { (alert and oriented to } \\
\text { person, place, and time } \\
\text { but not preceding } \\
\text { events). }\end{array}$ & $\begin{array}{l}\text { Recognize } \\
\text { pneumothorax } \\
\text { on x-ray }\end{array}$ & Provide students with a chest x-ray image (digital or paper copy). \\
\hline BP 110/80 & $\begin{array}{l}\text { Patient appears } \\
\text { physically agitated and } \\
\text { has increased work of } \\
\text { breathing. }\end{array}$ & $\begin{array}{l}\text { Needle } \\
\text { decompression }\end{array}$ & $\begin{array}{l}\text { If students do not know what to do after several minutes, radiology } \\
\text { will call stating the following: "This is radiology. We wanted to inform } \\
\text { you that on the STAT chest x-ray we see a tension pneumothorax and } \\
\text { advise that you perform a needle decompression." }\end{array}$ \\
\hline \multicolumn{4}{|l|}{ RR 26} \\
\hline \multicolumn{4}{|l|}{ SpO2 85\% } \\
\hline $\begin{array}{l}\text { Following } \\
\text { needle } \\
\text { decompression } \\
\text { SpO2 } 95 \%\end{array}$ & & & \\
\hline
\end{tabular}

\section{TABLE 2: Intermediate hypoxic state}

The table includes patient vitals and corresponding actions of all participants during the intermediate hypoxic state.

HR, heart rate; BP, blood pressure; RR, respiratory rate; SpO2, pulse oxygen.

Decompensation is a signal for students to reassess $\mathrm{ABCD}$, to identify what is contributing to a change in the patient's condition. Students may attempt to treat hypoxemia by applying supplemental oxygen. This action does not completely resolve the patient's symptoms or oxygen saturation (SpO2), in order to prompt further examination by the student. Upon examination of the airway and auscultation of lungs, students are expected to identify a tension pneumothorax as the cause of the patient's shortness of breath and chest pain. Chest $\mathrm{x}$-ray is not required to confirm the diagnosis, but a representative image is included if requested during the scenario (Figure 3). 


\section{Cureus}

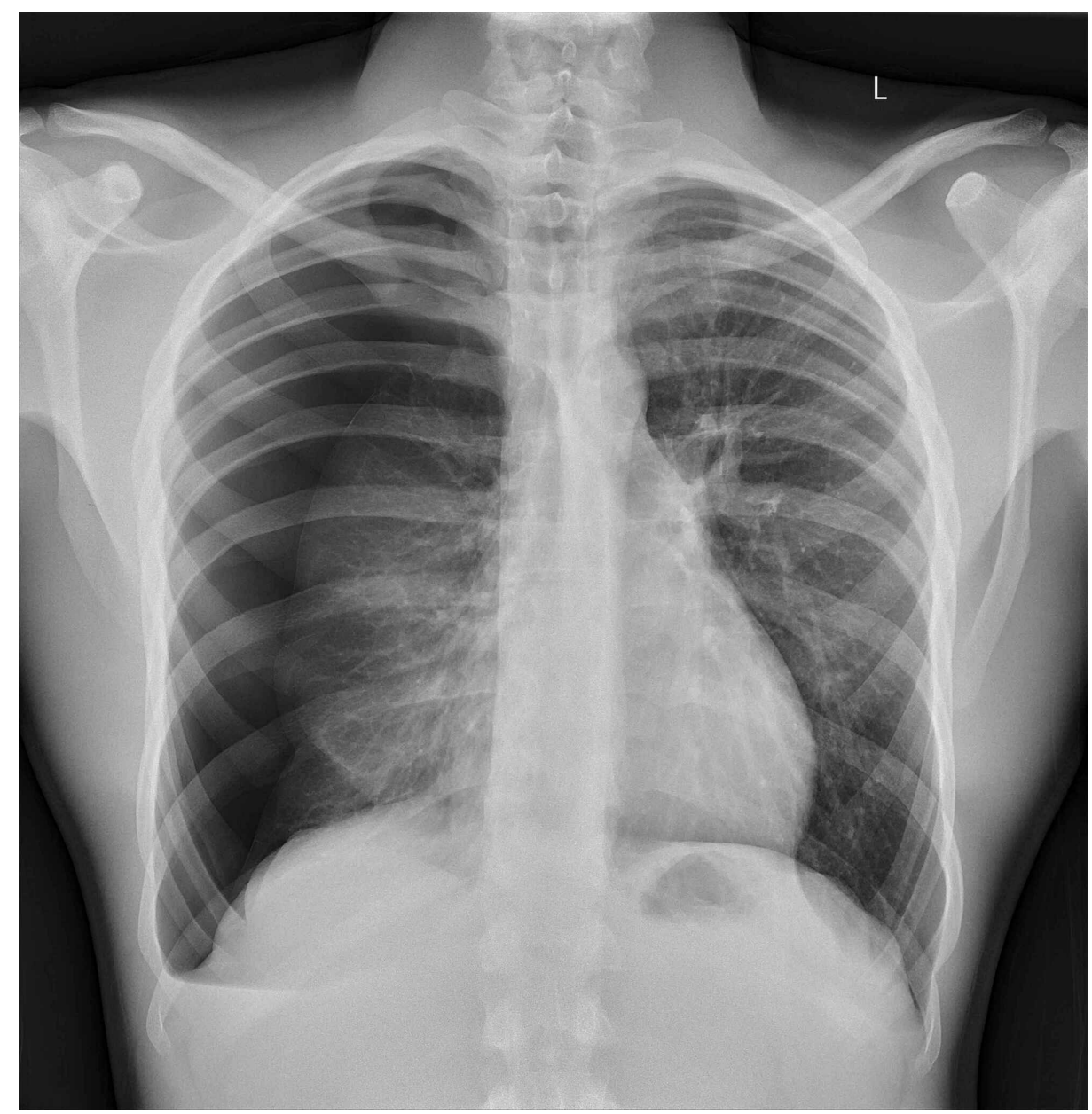

FIGURE 3: Chest x-ray showing tension pneumothorax

Case courtesy of Dr. Ana Brusic, Radiopaedia.org, rID: 60551.

Physical exam and vital signs concordant with tension pneumothorax in this scenario include decreased ventilation, hyperresonance to percussion, contralateral tracheal deviation, hypoxia, tachypnea, tachycardia, and rarely hypotension as a late complication [10]. Unstable patients may require emergency treatment by needle thoracostomy prior to radiographic confirmation of the diagnosis [11]. Verbalization of needle or chest tube thoracostomy is appropriate for this level of student. Advanced learners may demonstrate either skill on a task trainer.

After the verbalization of thoracostomy, the patient appears drowsy and begins complaining of head pain (Table 3). 


\section{Cureus}

\begin{tabular}{|c|c|c|c|}
\hline $\begin{array}{l}\text { Vital } \\
\text { signs }\end{array}$ & Patient status & Student actions & Operator notes \\
\hline $\begin{array}{l}\mathrm{HR} \\
110\end{array}$ & $\begin{array}{l}\text { Patient is } \\
\text { painplaining of head }\end{array}$ & Order head CT & $\begin{array}{l}\text { If students are unsure of next steps, healthcare actor may state "do } \\
\text { you think we need additional help" or "I think we need to call } \\
\text { neurosurgery." }\end{array}$ \\
\hline $\begin{array}{l}\text { BP } \\
110 / 80\end{array}$ & $\begin{array}{l}\text { Patient is confused } \\
\text { (now alert to person } \\
\text { only). }\end{array}$ & $\begin{array}{l}\text { Identify epıdural bleed on } \\
\text { imaging }\end{array}$ & \\
\hline RR 20 & & $\begin{array}{l}\text { Consult neurosurgery, giving a } \\
\text { brief report on the patient's } \\
\text { condition }\end{array}$ & \\
\hline $\begin{array}{l}\text { SpO2 } \\
95 \%\end{array}$ & & & \\
\hline
\end{tabular}

\section{TABLE 3: Altered mental status-secondary to traumatic brain injury (TBI)}

$\mathrm{CT}$, Computed tomography; HR, heart rate; $\mathrm{BP}$, blood pressure; RR, respiratory rate; SpO2, pulse oxygen.

Prompted by a change in neurologic status, students may assess impairment of consciousness using the Glasgow Coma Scale (GCS). The GCS is a clinical tool widely used in the treatment of trauma patients to simply communicate the severity of a patient's condition [12]. The patients opens their eyes spontaneously, has confused speech but follows commands, which equates to a GCS of 14. Students may follow up the GCS by assessing if the patient is alert and oriented to person, place, time, and preceding events ( $\mathrm{A} / \mathrm{O} \times 4 / 4)$. As students reassess the patient's level of orientation, the patient is alert and oriented $(\mathrm{A} / \mathrm{O}) \mathrm{x} 1 / 4$ (previously $\mathrm{A} / \mathrm{Ox} 3 / 4$ ), negative to time, place, and preceding events. Over time the patient becomes more somnolent and difficult to arouse. Physical examination reveals retroauricular and mastoid ecchymosis, colloquially termed "battle signs." Although battle signs usually present late in the clinical course, this physical exam finding is included for a simulation with novices in order to facilitate an association between this finding and significant neurologic injury. Additionally, this finding emphasizes the importance of a thorough secondary survey after completing the primary "ABCDE" assessment. A decrease in the level of consciousness in addition to head pain in the setting of trauma should prompt learners to consider a traumatic brain injury (TBI) and order computed tomography (CT) of the head (Figure 4). The goal of this state is for students to identify an epidural hematoma and consult neurosurgery. 


\section{Cureus}

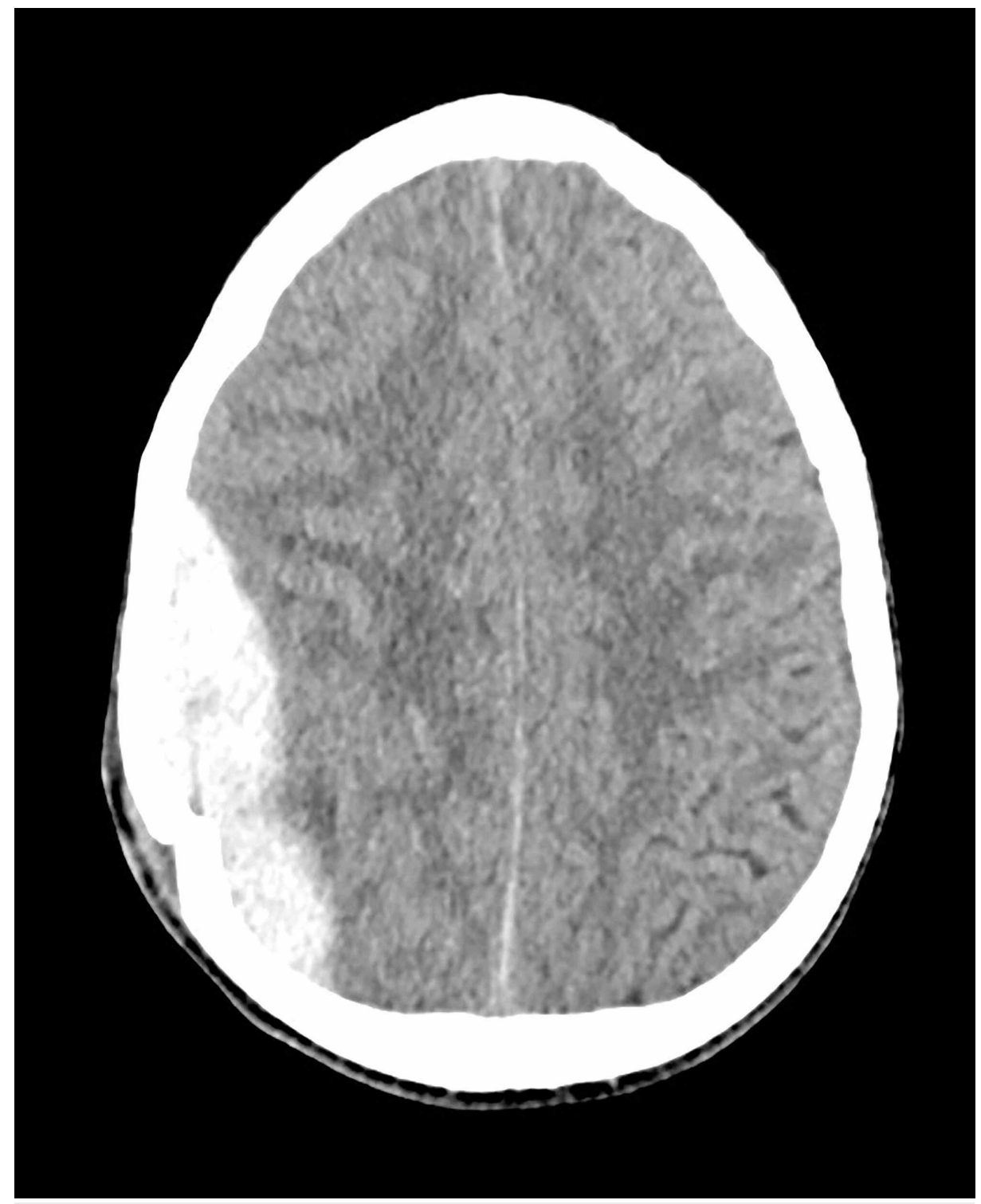

FIGURE 4: Epidural hematoma underlying a depressed skull fracture Case courtesy of Dr. Michael P Hartung, Radiopaedia.org, rID: 74815.

\section{Debriefing}

Debriefing of this simulation highlights elements of the assessment and management of a multisystem patient relevant at the preclinical medical student level. This includes identification and acute intervention of hemorrhage control from a femur fracture and thoracostomy for a tension pneumothorax while also identifying a TBI. Designing a multisystem trauma scenario assists in bolstering foundational anatomical knowledge and assessment of medical students' abilities to think critically in an emergent situation with an unstable patient.

Compound fractures are most often seen in middle-aged males with crush injuries due to motor vehicle accidents and falls from standing heights [13]. In patients with compound fractures, reduction in the ED may be required to achieve hemostasis [13]. Once the patient is stabilized they should receive prophylactic antibiotics and updated tetanus immunization as indicated. Definitive intervention for the fracture would include wound irrigation and debridement followed by surgical intervention for fixation and wound closure [13].

In addition to an obvious femur fracture, this simulation includes a tension pneumothorax resulting from a rib fracture. This is included to encourage students to examine a patient closely for injuries after sustaining a trauma significant enough to fracture one of the strongest bones in the body. In addition, students are able to identify compromised breathing and determine an appropriate intervention. The diagnosis of tension pneumothorax may be made clinically or confirmed with imaging. Appropriate management includes 
Lastly, it is critical that medical students suspect traumatic brain injuries in trauma patients with altered mental status since TBIs are the leading cause of death in this population [15]. In this scenario, students were provided with physical examination findings and imaging indicative of intracranial mass effect secondary to a basilar skull fracture and an ensuing epidural hematoma. It is well documented that mass effect has short- and long-term cognitive complications, such as changes in mental status, mood, and diminished health-related quality of life [16]. The clinical features of basilar skull fractures may present acutely in nonspecific ways, including altered mental status, nausea, vomiting, and cranial nerve deficits [17]. Other findings, such as hemotympanum, cerebrospinal fluid rhinorrhea or otorrhea, periorbital ecchymosis, and retroauricular ecchymosis, may not present until hours or days following the injury [17].

\section{Discussion}

This simulation was designed not only to test the students' medical knowledge but also to provide exposure to the continuum of care required to resuscitate a trauma patient. In order to mirror the environment (ED) in which the skill being taught (primary survey) would be practiced, careful consideration was given to the team-based approach for trauma patients; this includes pre-hospital EMS, ED trauma teams (including physicians, nurses, and technicians) as well as definitive care providers such as surgical and intensive care teams. Specifically, EMS crews have critical information about the mechanism of injury, timing of events, other patients at the scene, and tools that were required for extrication [18]. The role of EMS was given consideration in this scenario by including a handoff from the pre-hospital crew to the ED team via radio report.

Following receipt of a radio report, students were allowed to enter the room and were told to evaluate and treat the patient's life-threatening injuries. The expected actions for students to take were based on the primary survey consisting of assessment and management of $A B C D E$. Interventions were based on specific injuries identified through the primary survey, the most significant of which were traumatic brain injury, tension pneumothorax, and compound femur fracture. These conditions were progressively revealed to the students in order to emphasize the importance of reassessment as well as mitigation of cognitive overload.

Given the experience of targeted learners, trained HAs playing the role of ED nurses were included in the encounter. These individuals were trained on the flow of the case and instructed on when to intervene. Their interactions allowed the case to unfold in the order in which it was designed and provided the students some insight on next steps without taking away from the learning experience. Additionally, they limit distractions and nonproductive discussion. For more experienced learners, this scenario could be augmented by replacing trained HAs with clinical support staff not pre-briefed on the case flow. This would maintain the realism of the scenario and add a degree of difficulty.

\section{Conclusions}

Fall injuries are a common occurrence in adults of all ages. These events can lead to a variety of injuries impacting most body systems. As such, these scenarios are a valuable learning tool for medical students, residents, and seasoned physicians alike. This technical report provides a turn-key medical simulation that can be modified for a broad audience of students. Through methodical application of the primary survey, students can learn to effectively diagnose, manage, and treat a complex scenario in a safe learning environment.

\section{Appendices}

\section{Appendix A: Script}




\section{Cureus}

Name: George Highfall Age: stated age of SP Gender: M

Chief Concern: "I fell off a roof... and see what happened to my leg"

Case Overview: An approximately 20 year old male patient fell from a 20 foot roof. He landed on his right side with his leg take most of the force causing and obviously fractured femur, and bruised ribs which progress to cause a pneumothorax. During the fall his head was forcibly hyperextended, leading to a C2 fracture and posterior epidural bleed.

\begin{tabular}{|c|l|}
\hline Special Patient Instructions & $\begin{array}{l}\text { You are in pain, but your goal is to help teach the students NOT to } \\
\text { confuse the students by being overly dramatic. }\end{array}$ \\
\hline Demeanor & $\begin{array}{l}\text { Initially the patient is in pain, but not screaming. } \\
\text { As the case progresses the patient will become short of breath. After } \\
\text { this is treated with decompression, the patient will become lethargic } \\
\text { but able to be alerted. }\end{array}$ \\
\hline Attire & Cheap clothing that can be cut off or optionally pre-cut \\
\hline Physical Exam & Everything will be noted on monitor or a be stated over the speaker \\
\hline Vital Signs & See Case flow (appendix B) \\
\hline
\end{tabular}

FIGURE 5: Script Page 1 


\section{Cureus}

\begin{tabular}{|c|c|c|}
\hline & \multicolumn{2}{|l|}{ He } \\
\hline & $\begin{array}{l}\text { What is your name? George Highfall } \\
\text { How old are you? years old say your age }\end{array}$ & \\
\hline & $\begin{array}{l}\text { What brings you in? Or Why are you here today? } \\
\text { "I slipped on some leaves while I was working on the roof and fell." } \\
\text { How high was this fall? } \\
\text { "At least } 20 \text { feet" } \\
\text { Did you lose consciousness? } \\
\text { "I think I did. I am unsure" (If the team ask questions about what you last } \\
\text { remember say being on the roof and then the back of the ambulance) } \\
\text { Who called EMS/ } 911 \\
\text { Pause... "I am unsure" } \\
\text { Did you hit your head? } \\
\text { "I think I hit the back of my head." } \\
\text { Can you move your hands and feet? } \\
\text { You can move your figures and toes } \\
\text { Do you feel nauseated? } \\
\text { "A little" } \\
\text { Do you have neck pain? } \\
\text { "yes I do. Is that why I have this collar on" } \\
\text { Tell me about this pain. } \\
\text { "I hurt allover" "My right leg, chest, neck and back of my head" }\end{array}$ & \\
\hline $\begin{array}{c}\text { Femur } \\
\text { Questions }\end{array}$ & $\begin{array}{l}\text { **The leg should be the first thing you talk about and the team should focus } \\
\text { on your leg first*** } \\
\text { If the team tries to move your leg I need you to moan or show signs of great } \\
\text { distress. This also includes when they try to wrap it. (Do not scare the } \\
\text { students from wrapping your leg) } \\
\text { Where does your leg hurt? } \\
\text { Point to the leg "I think it's broke" } \\
\text { What does the pain feel like/ can you describe the pain? } \\
\text { "A deep sharp pain in the middle of my leg and it feels like my skin is ripped." } \\
\text { Does the pain in your leg radiate anywhere? } \\
\text { "No" } \\
\text { What did you fall into/ when you fell what did you land in? } \\
\text { "I land on the concreate or sidewalk. I don't think there was any dirt." }\end{array}$ & $\begin{array}{l}\text { These are questions that } \\
\text { students might ask about } \\
\text { the femur fracture. } \\
\text { You will have pulses on } \\
\text { your right foot. } \\
\text { There will not be a real } \\
\text { tourniquet in the room. }\end{array}$ \\
\hline
\end{tabular}

2

FIGURE 6: Script Page 2 


\section{Cureus}

\begin{tabular}{|c|c|c|}
\hline & $\begin{array}{l}\text { What do you think caused the break? } \\
\text { "I think the fall" } \\
\text { How long ago did this happen? } \\
\text { "pause... I am unsure" (remember you have a TBI + little confused) } \\
\text { What is your pain scale 0-10? } \\
\text { "10" } \\
\text { Do you have any numbness on Right leg? } \\
\text { "I think so, but I am not sure" }\end{array}$ & \\
\hline Confusion & $\begin{array}{l}\text { "Where am I ?" } \rightarrow \text { the team "the ER } \rightarrow \text { stay confused } \\
\text { "What happened to me?" } \\
\text { Repeat the above and become sleepy }\end{array}$ & $\begin{array}{l}\text { **After the team } \\
\text { decompresses the } \\
\text { patient's chest, the } \\
\text { patient becomes } \\
\text { confused and somnolent } \\
\text { (eyes closed and difficult } \\
\text { to wake) ** }\end{array}$ \\
\hline Neck pain & $\begin{array}{l}\text { Does your neck hurt? } \\
\text { "Yes it does. It feels similar to my leq, but it is higher up." }\end{array}$ & $\begin{array}{l}\text { **Remember you will } \\
\text { have a C- collar on. }{ }^{* * *} \\
\text { ** You can ask why the C- } \\
\text { collar is on and will they } \\
\text { do anything about it. } \\
\text { **If they try and remove } \\
\text { it: "They told me it could } \\
\text { only be removed after at } \\
\text { CT" }\end{array}$ \\
\hline $\begin{array}{l}\text { Localization of } \\
\text { pain }\end{array}$ & $\begin{array}{l}\text { Could you show me (or tell me specifically) where you are feeling this? } \\
\text { Early on in the case you can point and ID the pain }\end{array}$ & \\
\hline \multirow[t]{2}{*}{$\begin{array}{l}\text { Quality of the } \\
\text { pain }\end{array}$} & $\begin{array}{l}\text { How would you describe this pain? } \\
\text { If asked... "I hurt all over in a lot of spots and the pain is different in each spot" } \\
\text { Pain by region: } \\
\text { Leg= "sharp" } \\
\text { Chest = After the wound is addressed "it is hard to breathe" } \\
\text { Neck = "very painful and this thing on my neck is uncomfortable" } \\
\text { Head = "dull pain, it feels like my brain is rattling around" }\end{array}$ & $\begin{array}{l}\text { As the case moves on say } \\
\text { less and less }\end{array}$ \\
\hline & $\begin{array}{l}\text { On a scale of } 0-10 \text {, with } 0=\text { no pain and } 10=\text { worst pain you can imagine; how } \\
\text { would you rate your pain? } \\
\text { "It is a } 10 / 10 "\end{array}$ & \\
\hline $\begin{array}{c}\text { The patient } \\
\text { becomes short } \\
\text { of breath during } \\
\text { the }\end{array}$ & $\begin{array}{l}\text { What does the shortness of breath feel like? } \\
\text { "I feel like I can't take a deep breath"... } \\
\text { IF THE TEAM DOES NOT GET THE PNEUMO }\end{array}$ & \\
\hline
\end{tabular}

FIGURE 7: Script Page 3 


\section{Cureus}

\begin{tabular}{|c|c|c|}
\hline $\begin{array}{l}\text { intermediate } \\
\text { state }\end{array}$ & $\begin{array}{l}\text { "I feel like I only have only one lung." } \\
\text { Since it started has it been getting better or worse? } \\
\text { "Worse" }\end{array}$ & \\
\hline $\begin{array}{l}\text { Provocation of } \\
\text { pain }\end{array}$ & $\begin{array}{l}\text { What makes problems worse? } \\
\text { Bone/leg = "movement" } \\
\text { Chest = "deep breathing" } \\
\text { Head = "shaking or movement" } \\
\text { C-spine = "any movement at all" }\end{array}$ & $\begin{array}{l}\text { Use some judgement here } \\
\text { and yell out in pain or } \\
\text { groan when these } \\
\text { structures are examined. }\end{array}$ \\
\hline \multirow[t]{6}{*}{$\begin{array}{l}\text { Palliation of } \\
\text { pain }\end{array}$} & $\begin{array}{l}\text { What makes problem better? } \\
\text { "I am not sure just please fix my leq" }\end{array}$ & \\
\hline & $\begin{array}{l}\text { Do you have any other symptoms? } \\
\text { "Yes, I have ringing in my ear." Anything else "I feel dizzy" Anything else "I feel } \\
\text { short of breath" }\end{array}$ & \\
\hline & $\begin{array}{l}\text { What was the last thing that you ate? } \\
\text { "A hot dog with fries at noon." }\end{array}$ & \\
\hline & $\begin{array}{l}\text { How has this affected your life? } \\
\text { "I think I might actually die" }\end{array}$ & \\
\hline & $\begin{array}{l}\text { If I were to give you the following options: excellent, very good, good, fair, or } \\
\text { poor how would you rate your health? } \\
\text { "Very good before the fall" }\end{array}$ & \\
\hline & $\begin{array}{l}\text { As an adult, what medical conditions have you been told you have? } \\
\text { "High cholesterol" }\end{array}$ & \\
\hline \multirow[t]{3}{*}{ Medication } & $\begin{array}{l}\text { What prescription medications do you use? } \\
\text { "Atorvastatin" } \\
\text { What do you take it for? } \\
\text { "High cholesterol" } \\
\text { What is the dosage? How often? } \\
\text { "20mg daily" } \\
\text { Have you had any side effects? } \\
\text { "I'm not sure" } \\
\text { Do you take anything over the counter? } \\
\text { "No" }\end{array}$ & \\
\hline & $\begin{array}{l}\text { Are you allergic to anything? } \\
\text { "Nothing / know about" }\end{array}$ & \\
\hline & $\begin{array}{l}\text { Have you ever been hospitalized, surgeries or had an injury in the past? } \\
\text { "No" }\end{array}$ & \\
\hline
\end{tabular}

FIGURE 8: Script Page 4 


\section{Cureus}

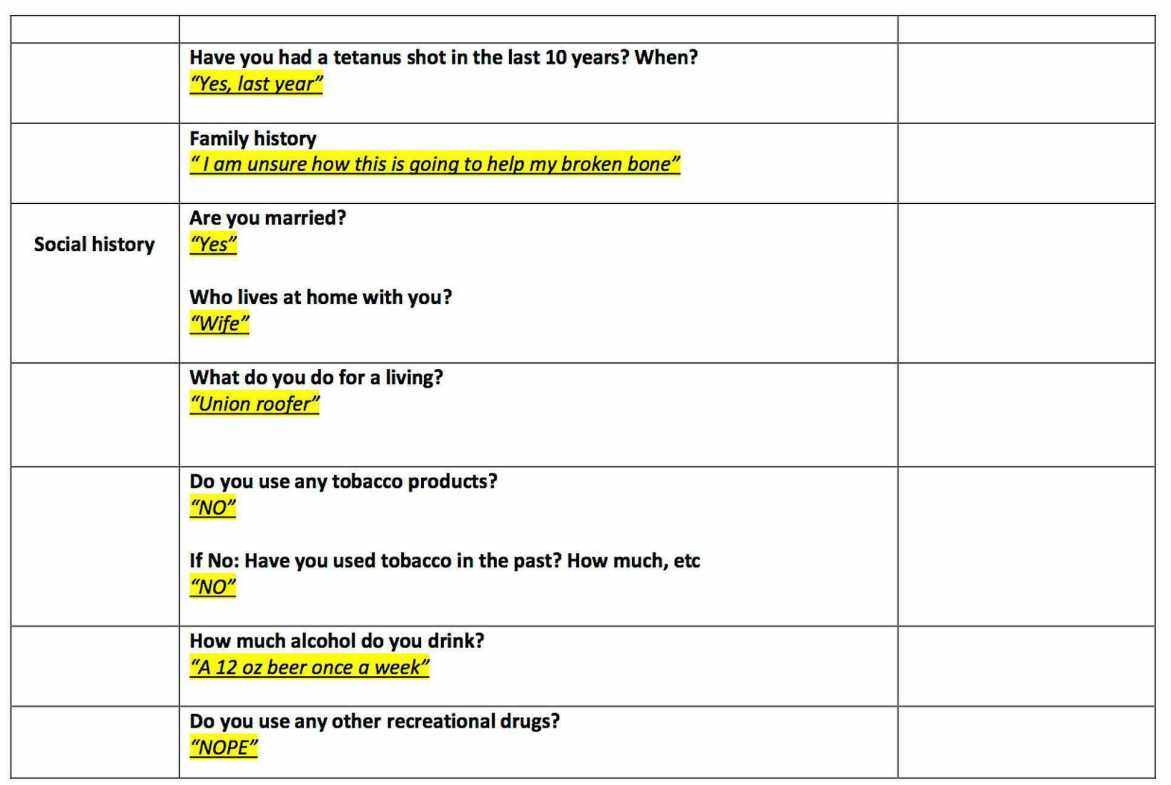

FIGURE 9: Script Page 5

\section{Appendix B: Case flow}




\section{Cureus}

\section{George Highfall - CASE FLOW SUMARRY}

Initial Hypotensive State
\begin{tabular}{|l|l|}
\hline BP: & $104 / 72$ \\
\hline HR: & 138 \\
\hline RR: & 22 \\
\hline SpO2: & 94 \\
\hline Temp: & 98.5 \\
\hline
\end{tabular}

Bleeding has been stopped + some history obtained

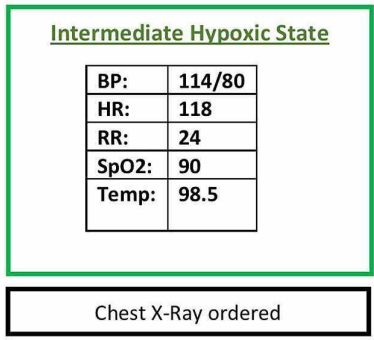

Decompensated Hypoxic State

\begin{tabular}{|l|l|}
\hline BP: & $110 / 80$ \\
\hline HR: & 142 \\
\hline RR: & 26 \\
\hline SpO2: & 85 \\
\hline Temp: & 98.5 \\
\hline
\end{tabular}

Needle decompression ordered or performed

\begin{tabular}{|l|l|}
\hline \multicolumn{2}{|l|}{ AMS/ TBI State } \\
\begin{tabular}{|l|l|}
\hline BP: & $110 / 80$ \\
\hline HR: & 110 \\
\hline RR: & 20 \\
\hline SPO2: & $95 \%$ \\
\hline Temp: & 98.5 \\
\hline
\end{tabular} \\
\hline
\end{tabular}

\section{Operator Notes}

If confused PT states: "Please help me- I think I am going to bleed"

If failure to address wound: "Please, I'm going to die if you don't stop the bleeding." Or have Health care actor help guide team.

If CT ordered: Hold until final state with AMS

$$
\begin{aligned}
& \quad \text { Operator Notes } \\
& \text { If confused PT states :“It feels like I have only one lung." } \\
& \text { If failure to order X-ray: Health care actor "Did, we order the all } \\
& \text { the necessary trauma films?" } \\
& \text { If x-ray ordered early in case: Allow for some time to pass before } \\
& \text { moving to decompensated hypoxic state. }
\end{aligned}
$$

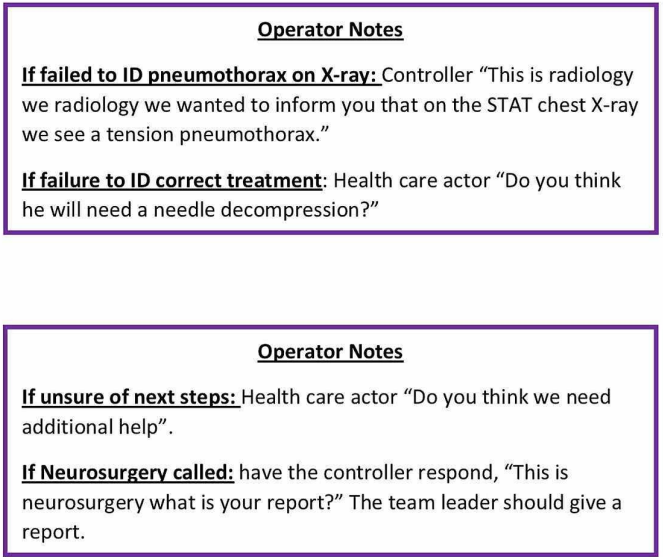

FIGURE 10: Simulation case flow

\section{Appendix C: Labs}




\section{Cureus}

Patient: George Highfall

\begin{tabular}{|l|c|l|}
\hline \multicolumn{2}{|c|}{ BASIC METABOLIC PANEL } & REFERENCE RANGE \\
\hline Sodium & 142 & $135-147 \mathrm{mmol} / \mathrm{L}$ \\
\hline Potassium & 4.2 & $3.5-5.2 \mathrm{mmol} / \mathrm{L}$ \\
\hline Chloride & 102 & $95-107 \mathrm{mmol} / \mathrm{L}$ \\
\hline CO2 & 27 & $22-30 \mathrm{mmol} / \mathrm{L}$ \\
\hline Urea Nitrogen (BUN) & 20 & $7-20 \mathrm{mg} / \mathrm{dL}$ \\
\hline Creatinine & 1.2 & $0.5-1.2 \mathrm{mg} / \mathrm{dL}$ \\
\hline Glucose & 88 & $60-110 \mathrm{mg} / \mathrm{dL}$ \\
\hline
\end{tabular}

\begin{tabular}{|c|c|c|c|}
\hline \multicolumn{2}{|c|}{ COMPLETE BLOOD COUNT } & \multicolumn{2}{|c|}{ REFERENCE RANGE } \\
\hline & & MALE & FEMALE \\
\hline White Blood Cell (WBC) & 8,000 & \multicolumn{2}{|c|}{$4,500-10,000 \mathrm{~K} / \mathrm{uL}$} \\
\hline Hemoglobin (HGB) & 13.5 & $13.5-16.5 \mathrm{~g} / \mathrm{dL}$ & $12.0-15.0 \mathrm{~g} / \mathrm{dL}$ \\
\hline Hematocrit (HCT) & 41 & $41-50 \%$ & $36-44 \%$ \\
\hline Platelet & $420 \mathrm{~K}$ & \multicolumn{2}{|c|}{$100,000-450,000 \mathrm{~K} / \mathrm{uL}$} \\
\hline
\end{tabular}

\begin{tabular}{|l|c|c|}
\hline \multicolumn{2}{|c|}{ TOXICOLOGY SCREEN } & REFERENCE RANGE \\
\hline Acetaminophen & 0 & $<10$ \\
\hline Salicylates & 0 & $<5$ \\
\hline EtOH & 0 & 0 \\
\hline Opiates & Negative & Negative \\
\hline Cocaine Metabolites & Negative & Negative \\
\hline Benzodiazepines & Negative & Negative \\
\hline Cannabis Derivatives & Negative & Negative \\
\hline Barbiturates & Negative & Negative \\
\hline Amphetamines & Negative & Negative \\
\hline
\end{tabular}

\section{FIGURE 11: Laboratory results}

\section{Appendix D: Fabrication of bleeding wound}

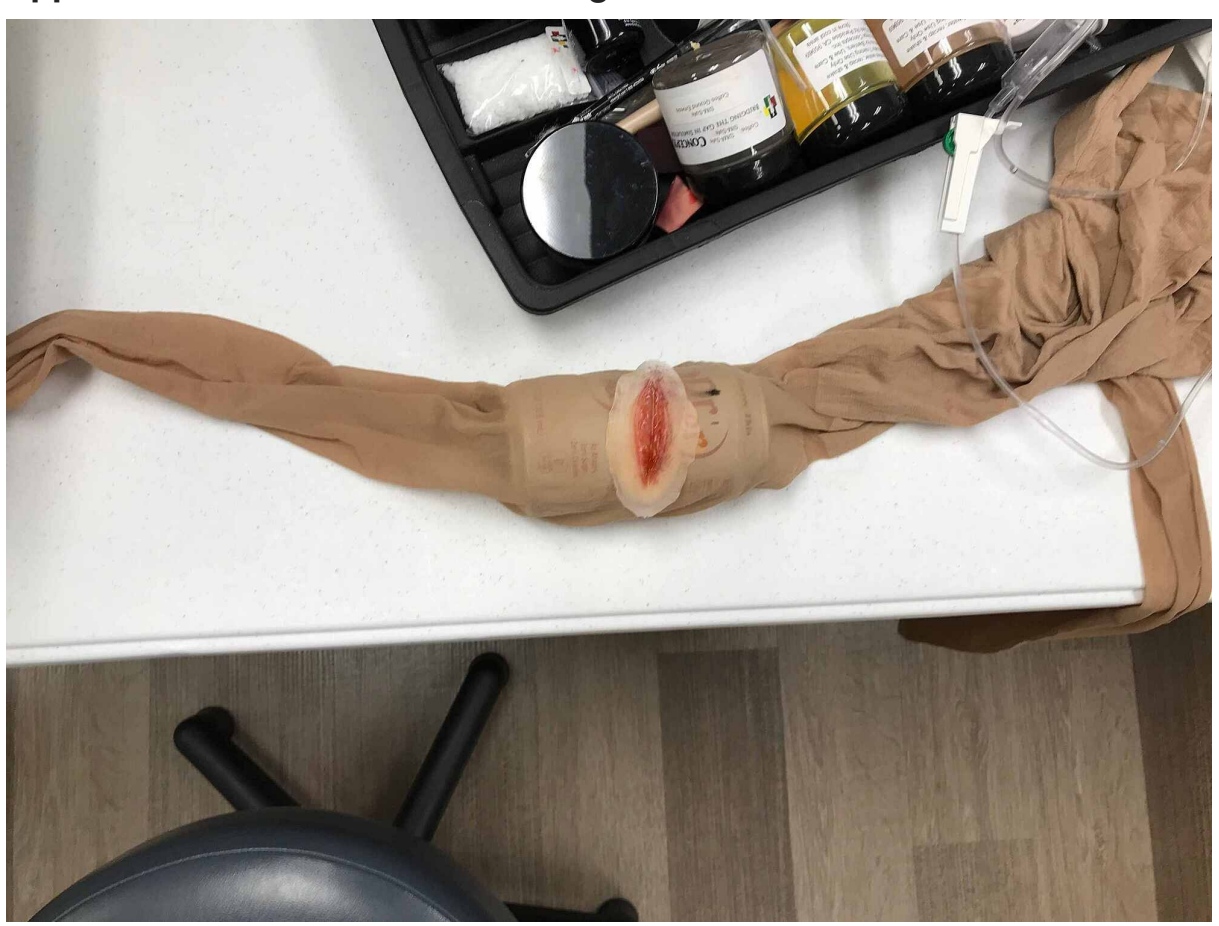

\section{FIGURE 12: Bleeding wound set-up}

The image shows the use of a soda can and nylon stockings to fabricate a bleeding laceration that can be applied to a SP. A soda can is inserted into the nylon stockings as a placeholder as adhesive binds a silicone laceration injury to the stockings. Intravenous tubing ran through the inside of the nylon material and is connected to a bag of prop blood and fashioned to the silicone piece. The soda can then be removed, and the nylon apparatus can be applied to the extremity of a SP. 


\section{Additional Information}

\section{Disclosures}

Human subjects: All authors have confirmed that this study did not involve human participants or tissue. Animal subjects: All authors have confirmed that this study did not involve animal subjects or tissue. Conflicts of interest: In compliance with the ICMJE uniform disclosure form, all authors declare the following: Payment/services info: All authors have declared that no financial support was received from any organization for the submitted work. Financial relationships: All authors have declared that they have no financial relationships at present or within the previous three years with any organizations that might have an interest in the submitted work. Other relationships: All authors have declared that there are no other relationships or activities that could appear to have influenced the submitted work.

\section{References}

1. DiMaggio C, Ayoung-Chee P, Shinseki M, et al.: Traumatic injury in the United States: in-patient epidemiology 2000-2011. Injury. 2016, 47:1393-1403. 10.1016/j.injury.2016.04.002

2. Segui-Gomez M, MacKenzie EJ: Measuring the public health impact of injuries . Epidemiol Rev. 2003, 25:319. 10.1093/epirev/mxg007

3. Timsina LR, Willetts JL, Brennan MJ, Marucci-Wellman H, Lombardi DA, Courtney TK, Verma SK: Circumstances of fall-related injuries by age and gender among community-dwelling adults in the United States. PLoS One. 2017, 12:0176561. 10.1371/journal.pone.0176561

4. Sise RG, Calvo RY, Spain DA, Weiser TG, Staudenmayer KL: The epidemiology of trauma-related mortality in the United States from 2002 to 2010. J Trauma Acute Care Surg. 2014, 76:913-919. 10.1097/TA.0000000000000169

5. Frydrych LM, Keeney-Bonthrone TP, Gwinn E, Wakam GK, Anderson MS, Delano MJ: Short-term versus long-term trauma mortality: a systematic review. J Trauma Acute Care Surg. 2019, 87:990-997. 10.1097/TA.0000000000002430

6. Butcher N, Balogh ZJ: The definition of polytrauma: the need for international consensus . Injury. 2009, 40:12-22. 10.1016/j.injury.2009.10.032

7. Jabaay MJ, Grcevich LO, Marotta DA, Reynolds JH: Trauma and triage: applying the dick and carey instructional design model to a primary survey clinical workshop. Cureus. 2020, 12:8656. 10.7759 /cureus.8656

8. Adler MD, Overly FL, Nadkarni VM, et al.: An approach to confederate training within the context of simulation-based research. Simul Healthc. 2016, 11:357-362. 10.1097/SIH.0000000000000172

9. Drew B, Bennett BL, Littlejohn L: Application of current hemorrhage control techniques for backcountry care: part one, tourniquets and hemorrhage control adjuncts. Wilderness Environ Med. 2015, 26:236-245. 10.1016/j.wem.2014.08.016

10. Roberts DJ, Leigh-Smith S, Faris PD, et al.: Clinical presentation of patients with tension pneumothorax: a systematic review. Ann Surg. 2015, 261:1068-1078. 10.1097/SLA.0000000000001073

11. Currie GP, Alluri R, Christie GL, Legge JS: Pneumothorax: an update. Postgrad Med J. 2007, 83:461-465. 10.1136/pgmj.2007.056978

12. Teasdale G, Jennett B: Assessment of coma and impaired consciousness: a practical scale . The Lancet. 1974, 2:81-84. 10.1016/S0140-6736(74)91639-0

13. Halawi MJ, Morwood MP: Acute management of open fractures: an evidence-based review . Orthopedics. 2015, 38:1025-1033. 10.3928/01477447-20151020-12

14. MacDuff A, Arnold A, Harvey J, BTS Pleural Disease Guideline Group: Management of spontaneous pneumothorax: British thoracic society pleural disease guideline 2010. Thorax. 2010, 65:18-31. 10.1136/thx.2010.136986

15. Vella MA, Crandall ML, Patel MB: Acute management of traumatic brain injury . Surg Clin North Am. 2017, 97:1015-1030. 10.1016/j.suc.2017.06.003

16. Marotta D, Tucker Z, Hayward EN, et al.: Relationship between cognitive functioning, mood, and other patient factors on quality of life in metastatic brain cancer. Psychooncology. 2020, 29:1174-1184. 10.1002/pon.5401

17. Simon LV, Newton EJ: Basilar skull fractures. StatPearls. Treasure Island. 2020,

18. Fedor PJ, Burns B, Lauria M, Richmond C: Major trauma outside a trauma center: prehospital, emergency department, and retrieval considerations. Emerg Med Clin North Am. 2018, 36:203-218. 10.1016/j.emc.2017.08.010 